\title{
Promoting strategy research on blended teaching mode reform in colleges and universities: a case study in China
}

\author{
Hongtao Yu \\ College of Journalism and Communication, \\ Inner Mongolia University for Nationalities, \\ Tongliao, 028000 China \\ Email: 111yuhongtao@163.com
}

\begin{abstract}
The purpose of this paper is to construct promoting strategies for effective blended teaching reform for higher education. Based on the literature review of promoting strategy research on blended teaching model reform in colleges and universities both in China and abroad, this paper puts forward five promoting strategies for blended teaching mode reform in China. After the practice during a semester, the promoting strategies have proved to be effective in creating a suitable atmosphere for the blended teaching reform, promoting teachers' teaching ability and improving students' study initiative and competency.
\end{abstract}

Keywords: blended teaching; guarantee system; reform; research.

Reference to this paper should be made as follows: Yu, H. (2017) 'Promoting strategy research on blended teaching mode reform in colleges and universities: a case study in China', Int. J. Social Media and Interactive Learning Environments, Vol. 5, No. 1, pp.79-86.

Biographical note: Hongtao, Yu (1975), Associate Professor in College of Journalism and Communication in Inner Mongolia University for Nationalities. He got MA majoring in Educational Technology, and his major research focuses on online education, with publications of 2 books, more than 20 journal articles and has taken charge of several research projects.

\section{Introduction}

With the increasing development of internet, modern online education is rapidly gaining traction in countries of higher information level such as America, the UK, Australia, Japan and so on. Blended teaching mode reform has become a major issue in colleges and universities both in China and abroad. It has undergone thorough practice abroad, with systematic administration and practice mode established, which is a valuable experience worthy of being used for reference by colleges and universities in China in order to figure out a teaching reform mode of its own characteristics. According to 'the Horizon Report for 2015' (Higher Education) issued by USA (www.nmc.org), blended teaching and flipped classroom are among them and will be widely applied in 1-2 years. 
Although blended teaching is a hot research issue, according to literature both in China and abroad, the research findings mainly focused on the reform of blended learning in just one particular course (Dongmei and Yi, 2012), on the evaluation of effects under blended teaching (Maosen et al., 2015), on the different modes of blended teaching (Shuqiang et al., 2014) and on the application of web-based teaching platform (Chaoqun et al., 2010). There are less research findings concerning institutional level of blended teaching. In the research report "To greet digital university: Discussion on long distance, blended and online learning" made by George Siemens, it is pointed out that "in our literature review, we only found just one piece of writing that systematically deals with blended learning practice from the institutional level" (Xibin et al., 2016). Meanwhile, some scholars also pointed out the research gap, "On one hand, there is not enough research on the teacher's role in blended learning; and on the other hand, due to lack of teacher training and information about policy and practice of blended learning, there is not enough research on the teacher's and institutions' view on blended teaching" (Drysdale et al., 2013). In China, there are but a few colleges and universities practicing systematic blended teaching reform and still there are less successful experience. Compared with traditional teaching methods, blended teaching proved to have distinctive advantages, which, however, has encountered certain obstruction during implementation in colleges and universities. How to gain an overall promotion of blended teaching reform from the institutional level has become a key issue for further research (Owston, 2013). Therefore, it is pressed for urgent solution to construct promoting strategies for effective blended teaching reform for higher education.

Graham et al. (2013) have conducted a research by investigating blended teaching process in six colleges in America. And they divided the process as belief/explore, adoption/preliminary implementation and mature implementation/developing stages, with a frame for adopting and implementation of blended learning being put forward. Poter et al. (2014) adopted this frame for a follow-up study on the procedure of blended learning in 11 American universities. It had three stages: strategy, i.e. to make a whole scheme and top-level design for the blended teaching, including the definition, propagandising form, implementation scope, implementation objectives and corresponding project policies; organisation, i.e. to implement the procedure and establish a frame for technology, teaching, administration, including regulations, modes, curriculum arrangement and assessment; support, i.e. to guarantee the implementation, including support for technology, teaching, motivation system for teachers and so on. In this model, there is no mentioning about the teacher's role in blended learning. And in order to effectively carry out blended learning reform in universities, five promoting strategies are put forward based on the literature and combined with university characteristics of China, including top-level design, construction of training system, construction of supervisory and feedback system, construction of teaching motivation scheme, and construction of service system for blended teaching reform. 


\section{Context and implementation}

\subsection{Top-level design for blended teaching reform}

\subsubsection{Establishment of specialised agency for blended teaching reform}

In promoting blended teaching reform in the university, many elements are involved including administrative staff, teachers, students and technicians for support, as well as office of teaching affairs, faculty development centre, educational-technical centre, network centre and other administrative sections. The clear-cut responsibility for each section and coordination among them are critical for effective blended teaching reform. So in order to effectively promote the reform, a leading group should be formed with vice president in charge of teaching as the head, the directors of teaching affair office, faculty development centre, network centre and deans in charge of teaching in all institutes as members. Office of teaching affairs is the leading group office.

\subsubsection{Introduction of corresponding documents on blended learning reform}

In order to promote blended teaching reform, many documents are issued including "Classroom Teaching Reform Implementation in IMUN," "Construction Regulations on Courses with Blended Learning," "Construction Standards for Online Courses" and so on. In the above documents, the objectives, construction tasks, requirements, steps, guarantee system, motivation measures, course construction standards for blended teaching reform are clearly defined.

\subsection{Training system for blended learning reform}

\subsubsection{Training system for theory to practice}

To carry out blended teaching reform, the first thing is to change administrators and teachers' beliefs, and to improve teacher's competency in teaching designs. Therefore, a series of training programs are targeted and conducted, including training on teaching beliefs for deans of schools and heads of teaching and research sections; training on teaching design and how to involve network teaching platform for teachers who are involved in the reform; generalising training for teachers who are not involved in the blended learning reform. Besides, regular experience exchanges and saloons are held. The training should be done step by step, and consistently run through the reform for the teachers to come to understand and be accustomed to be involved in the teaching mode, from beliefs, course design, network platform employment to cases.

\subsubsection{Combination of intra-school and inter-school training}

For training, both training forms in our university and other universities are adopted, and gradually will become the school-based training. In 2015, the university has arranged four trainings with experts in China and abroad. In February July, 2016, 26 and 34 teachers were, respectively, assigned to Tsinghua University to participate in the promotion training on blended teaching. 
The course design training for the second group of teachers involving in the reform has been completed by the teachers and experts in the university and five trainings have been conducted in 2016 .

\subsubsection{Generalisation of blended learning practice and experience by way of training in each school in the university}

From this semester on, the Office of Teaching Affairs, together with the Faculty Development Center, has enacted "Implementation plan for blended teaching reform and correspondent training in IMUN." And blended learning practice and experience are going to be generalised by way of training in each school with practical cases. Namely, before the meeting-time, all the administrators and teachers in the school will have such kind of training within 1 or $2 \mathrm{~h}$. Every week we will conduct the training in one school of our university.

\subsection{Construction of supervisory and feedback system on blended learning reform}

"Standards for online courses in IMUN" is undergoing development, including assessment of teaching quality from four dimensions: course information, teaching resources, activities and implementation procedure. And the assessment will be published regularly. Those courses which did not meet the standards or were of poor teaching effect, will not be allowed to continue. There are 33 courses being the first group that have undergone the reform, 1 of them failed in the final evaluation. And there are 70 courses being the second group with 1 failing.

For monitoring, supervisors for teaching and deans in charge of blended teaching reform will attend at intervals the lectures of the courses and track the process for the whole term.

Educational Technology Institute of Tsinghua University and Educational Technology Section in the university are responsible for design evaluation on the blended learning courses.

Meetings among students and teachers, respectively, are held in order to get feedback for the reform, solve the problems arising in the process and complete the grantee system for blended teaching reform.

\subsection{Construction of teaching motivation scheme for online education and blended learning reform}

Both internal and external motivation schemes are constructed, with internal one aiming at motivating teachers to have stimulated responsibility by way of consistent training and achievements in the classroom reform.

External one refers to 50,000 yuan sponsored by the university for each pilot school to implement course reform, 2,000 yuan for each course in non-pilot school. In order to motivate teachers to be absorbed in teaching and actively explore teaching reform, the final allowance paid will increase by 1.2. All the reform courses which have passed the evaluation will be granted as university-sponsored projects, which are the important provisions for the professional title appraisals. 
Apart from the above, expenditure in each school has to cover budget on online courses and blended learning course development.

\subsection{Construction of service system for blended teaching reform}

Reform group for blended teaching reform from Tsinghua University, Educational Technology Section, the Network Center and Faculty Development Center in our university provide service for the blended teaching reform. The group from Tsinghua University offers support in maintaining servers, learning and teaching beliefs, network employment, course design and so on. Educational Technology Section in our university is responsible for counselling through WeChat or telephone. The Network Center offers online service and Faculty Development Center is in charge of training.

According to the survey, teachers who participate in the reform held $90.7 \%$ of the satisfaction degree towards the service offered by Educational Technology Section. $30.26 \%$ of the teachers sought help in WeChat, $11 \%$ of them by phone. In this semester, more than 1,000 questions raised by the teachers have been solved in terms of blended teaching reform.

\section{Results and discussion}

\subsection{Excellent courses with blended teaching have been constructed and the teaching mode has transferred from teaching-centred to learning-centred}

After 1 year's implementation, the university has had 103 courses with blended teaching mode. Among the 33 courses that first underwent the reform, 32 courses have passed the final evaluation; 70 courses as the second group and 69 passed. At present, there are altogether 101 blended learning courses, with complete course information on the platform, teaching resource construction such as PPT and test library. All the courses have different online activities such as online assignments, discussion, testing and so on. Besides, 192 courses have been granted by the university for resource construction of online teaching platform. Up to 21 July, online teaching platform has been visited for 870,000 times. In all, 412 teachers and 8,914 students have registered in the platform. Course construction based on blended learning reform has played a very important role in intensifying teaching mode reform, improving learners' competency and promoting the transference of teaching mode from teaching-centred to learning-centred.

\subsection{A series of training have built a good atmosphere of blended teaching reform and teachers' teaching competence has been improved}

Since the implementation of the reform, 19 trainings with 1,265 teachers and staff have been conducted by Educational Technology Section, Faculty Development Center and Educational Technology Institute of Tsinghua University. By way of training, the teachers' beliefs on the necessity of the reform have been deepened and their teaching competence has got improved.

In the next half year, Educational Technology Section, together with Faculty Development Center, will generalise blended teaching in 11 units such as College of 
Communication, College of Music, Foreign Language Teaching Department and so on. The survey shows that $93.9 \%$ of the teachers in our university think that it is necessary to conduct classroom teaching reform and $89.2 \%$ of them are willing to try blended instruction in their classroom teaching.

A series of training have offered a platform for teachers from different schools and disciplines to exchange teaching modes and methods. For those who have not participated in the reform, they actively apply for the reform for their courses; for those who have participated, they have implemented course design online and blended teaching design. The course design competency has developed to a great extent. The data show that in the excellent teaching plan appraisal by the university, there are 24 teachers conducting blended learning reform among the 39 teachers who won the appraisal $(61.5 \%)$.

\subsection{Blended teaching mode motivates students in their learning}

Since blended teaching emphasises online and offline study, different activities such as preview online, online self-testing before the class, classroom discussion, written assignment and so on effectively promote students' learning motivation. After 1 year's practice, the students have been accustomed to as well as acknowledged blended teaching mode. The survey conducted in the first half period of 2016 has shown that $82.89 \%$ of the teachers think that blended learning do motivate students to learn. A total of $95.24 \%$ of the students think so, with an increase of $2.12 \%$ compared with the last semester. A total of $93.24 \%$ of the students like blended teaching mode, with an increase of $2.1 \%$. A total of $92.8 \%$ of the students show satisfaction with online assignments, online teaching evaluation and online discussion, with an increase of $6.16 \%$. A total of $94.1 \%$ of the students think it is worthy to have online learning of the course, with an increase of $3.9 \%$ compared with the last semester.

\subsection{Blended teaching reform has enhanced learning efficacy}

Since in blended teaching, students' role has changed from passive listeners to active learners. Their reading ability, information acquisition and analysis ability and verbal expression have been reinforced. According to the survey, $93.7 \%$ of the students think that they have got improved a lot in the process of blended learning, and $76.2 \%$ of the teachers think that compared with traditional teaching mode, blended instruction has enhanced teaching efficacy.

In order to be clear about the facilitating role of blended learning for teaching efficacy, a comparative analysis on the final grades in the second group of blended teaching courses has been conducted laterally and vertically. In the university, the examination items are selected from the test library and each examination paper is graded by 3 or 4 teachers, so the final grades can be an objective and comprehensive refection of the student's learning efficacy. The data show that in the 30 courses with blended learning mode, the average score and pass rate of the 23 courses are higher than those in the comparison classes $(76 \%)$.

Besides, the data also show that in blended teaching mode, the final examination score of Mongolian students has been eminently improved. For instance, in the course of Elementary Mathematics II, the average score of the experiment class is higher than that in the comparison class by 24.84 points. In the course named College English II, by 17.4 points. In the course named Mongolian Medicine Processing, by 20.9 points. 
The characteristics of blended teaching are as follows: it is convenient for teachers to track students' learning process after class; it can drive forward the students to do selflearning after class by online assignments or online tests; it can broaden students' knowledge scope with uploaded learning references on the network platform. It is in accordance with the teaching objectives and emphasises the formative evaluation of teaching and learning process. The final score of the course is a very important teaching element and reference for teachers to be clear about the learners' learning status. The data show that the final score of the courses with blended instruction is higher than the comparison classes.

\section{Conclusion}

In this study, five promoting strategies for blended learning reform are put forward based on the three stages of blended teaching and implementation frame advocated by Graham et al. (2013). After 1 year's practice, the promoting strategies constructed in this study have played a facilitating role in generalising blended teaching mode for higher education, improving teaching competence, motivating students' to learn and improving students' learning efficacy.

\section{Acknowledgements}

This article is one of the achievements of the research project sponsored by Ministry of Education in China - "Research on Guarantee System of Blended Teaching Model Reform in Higher Education" (ID: 2016B120).

\section{References}

Chaoqun, G., Yongfeng, D. and Maoli, Z. (2010) 'Application of SAKAI platform in blended learning', e-Education Research, Vol. 8, No. 8, pp.89-92.

Dongmei, Z. and Yi, Y. (2012) 'Study on the teaching practice of blackboard-based blended learning mode', Modern Educational Technology, Vol. 22, No. 9, pp.41-43.

Drysdale, J.S., Graham, C., Spring, K.J. and Halverson, L.R. (2013) 'An analysis of research trends in dissertations and theses studying blended learning', The Internet and Higher Education, Vol. 17, No. 17, pp.90-100.

Graham, C.R., Woodfield, W. and Harrison, J.B (2013) 'A framework for institutional adoption and implementation of blended learning in higher education', The Internet and Higher Education, Vol. 18, No. 18, pp.4-14.

Maosen, X., Jialu, Z. and Wu, W. (2015) 'On learning effectiveness of blended learning model based on learning network', Journal of Sichuan University for Nationalities, Vol. 24, No. 5, pp.101-108.

Owston, R. (2013) 'Blend learning policy and implementation: introduction to the special issue', Internet and Higher Education, No.18, pp.1-3.

Porter, W.W., Graham, C.R., Spring, K.A. and Welch, K.R. (2014) 'Blended learning in higher education: institutional adoption and implementation', Computer and Education, Vol. 75, No. 75 , pp.185-195. 
Shuqiang, S., Xuan, G. and Xiaoliu, Z. (2014) 'From flipped classroom to flipped conference: a study on academic conference mode and its technology-supported platform in $\mathrm{O}_{2} \mathrm{O}$ environment', Journal of Distance Education, Vol. 223, No. 4, pp.38-47.

Xibin, H., Yuping, W. and Tiedao, Z. (2016) To Greet Digital University: Discussion on Long Distance, Blended and Online Learning, Tsinghua University Press, Beijing. 